\title{
Fulfilment of righteousness: Historical and ontological perspective of Matthew 3:15
}

\author{
Authors: \\ Paul R. McCuistion ${ }^{1,2}$ \\ Colin Warner ${ }^{1,2}$ \\ Francois P. Viljoen ${ }^{2}$ \\ Affiliations: \\ ${ }^{1}$ Saint Leo University, United \\ States \\ ${ }^{2}$ Faculty of Theology, \\ North-West University, \\ Potchefstroom Campus, \\ South Africa \\ Correspondence to: \\ Paul McCuistion \\ Email: \\ teaching4jesus@msn.com \\ Postal address: \\ Saint Leo University, Florida, \\ United States \\ Dates: \\ Received: 09 July 2013 \\ Accepted: 06 Nov. 2013 \\ Published: 21 May 2014 \\ Republished: 22 May 2014 \\ How to cite this article: \\ McCuistion, P.R., 2014, \\ 'Fulfilment of righteousness: \\ Historical and ontological \\ perspective of Matthew \\ 3:15', In die Skriflig 48(1), \\ Art. \#1695, 8 pages. http:// \\ dx.doi.org/10.4102/ids. \\ v48i1.1695 \\ Note: \\ Article republished with the \\ correct affiliation for Francois \\ P. Viljoen.
}

\section{Copyright:}

(C) 2014. The Authors.

Licensee: AOSIS

OpenJournals. This work

is licensed under the

Creative Commons

Attribution License.
Read online:

Scan this $Q R$ code with your smart phone or mobile device to read online.
This article maintained that the historicity of Jesus' baptism was intended to flesh out the righteousness of God that was well-documented in the Hebrew Scriptures. Furthermore, the historical event initiated the ontological emphasis on the relationship of baptism to righteousness. To support this proposal, this article focused on Matthew's fulfilment statement in Matthew 3:15. Looking specifically at this verse within its context, the article examines what Matthew may have intended for his community to grasp regarding the Christian tradition of righteousness. The article is divided into four sections that are intended to examine Matthew's intentions. Firstly, the immediate context is examined, showing the influences and setting for the fulfilment statement. The following section explores the fulfilment statement within this context. The third section uncovers some of the theological traditions in Paul and the church fathers. Finally, the baptismal statement of Matthew 3:15 will be tied directly to the relationship of the law and righteousness in Matthew's $\tilde{\eta} \lambda \theta$ ov statement of Matthew 5:17.

Die verwesenliking van geregtigheid: ' $n$ Historiese en ontologiese perspektief van Matteus 3:15. Hierdie artikel betoog dat die historiese waarheid van Jesus se doop bedoel was om die geregtigheid van God, wat volledig uiteengesit is in die Hebreeuse Bybel, te versterk. Verder het die historiese gebeurtenis die ontologiese klem op die verhouding van die doop tot geregtigheid geïnisieer. Om hierdie voorstel te ondersteun, fokus hierdie artikel op Matteus se verklaring van verwesenliking (Mat 3:15). Deur spesifiek na hierdie vers binne sy konteks te kyk, ondersoek die artikel wat Matteus moontlik beplan het sodat sy gemeenskap die Christelike tradisie van geregtigheid kon begryp. Die artikel is in vier afdelings verdeel om sodoende Matteus se bedoelings te ondersoek. Eerstens word die onmiddellike konteks ondersoek wat die invloede en agtergrond van die verklaring van die verwesenliking uitwys. In die volgende afdeling word die verklaring van die verwesenliking in hierdie konteks verken. In die derde afdeling word 'n paar van die teologiese tradisies van Paulus en die kerkvaders aan die lig gebring. Ten slotte is die doopverklaring van Matteus 3:15 regstreeks aan die verhouding van reg en geregtigheid in Mattheus se $\tilde{\eta} \lambda \theta$ ov verklaring van Matteus 5:17 gekoppel.

\section{Introduction}

Davies and Allison (1988:323-324) list what they consider to be the seven most viable answers regarding how Jesus' baptism fulfils all righteousness:

1. It was the Messiah's task to bring the total will of God.

2. Jesus' baptism illustrated Jesus' death.

3. It was an example to Christians.

4. All divine ordinances, of which baptism is one, must be fulfilled.

5. Jesus validated John's ministry.

6. It was a right action intended to remove offense.

7. Jesus was fulfilling prophecy.

This list makes it obvious that scholarship has not been in agreement with Matthew's intent by including this into his gospel. Thus, this raises the overarching question of what Matthew's post-resurrection community may have drawn from this account. This article offers one possible option to this question.

Matthew's Jewishness is a matter of much debate. Nonetheless, it is the most fertile of the Gospels for discovering the relationship between the Hebrew ideal of covenant and the Christological understanding of the reign of heaven. The primary reason is that Matthew's Gospel is dominated by a structure that provides, for the most part, a Jewish viewpoint for his work. Guthrie (1990:32) maintains that this dominance is realised in the Old Testament citations and allusions that must obviously be a prime consideration in discussing the author's purpose. However, scholarship as 
a whole does not agree with the Jewish nature of the gospel. The debate regarding the Jewishness of Matthew ranges from a true respect for Judaism where Jesus' teachings mirrors their law, 'making Matthew the most Jewish of the Gospels' (Eliott 1992:359) to Matthew as an anti-Jewish Gospel that rewrites Mark, allegorises the key parables and gives the commission to evangelise Gentiles, not Jews (Cook 2008:192202). The gospel is, nevertheless, Jewish in orientation so that the author can support his opening statement and its ramifications, especially in relationship to the concept of fulfilment ( $\pi \lambda \eta \rho o ́ \omega)$.

Whilst the Jewish orientation is understood, and thus a Jewish background anticipated, it is not within the scope of this article to develop the Hebrew concept of righteousness. Nor is it the focus of this article to define righteousness. This articles starts in the same place Matthew does, and that is with an understanding that the Hebrew concept of righteousness is bound irrevocably to the nature of God and the law. Rather, this article intends to explore the historicity of the fulfilment event and the resulting ontological effect on the developed theology of the baptism.

To accomplish this, the article will first introduce the immediate concept of the fulfilment statement and then set the stage for the Matthean narrative. Next, Matthew 3:15 will be explored, examining what may have been intended as an ontological explanation for righteousness that becomes the foundation upon which all right acts, whether God's or humanity, are built. After this examination, the article will take a brief look at the church fathers and how they understood Jesus' baptism as it relates to this concept. In view of Matthew's insistence on right acts in the Sermon of chapters 5 to 7 , an important connection will be demonstrated between Matthew's larger cultural context and the link to his fulfilment statement in Matthew 5:17. Methodology will include historical and form critical approaches to the text. Additionally, linguistic and philosophical insights will contribute to the examination of the concept.

\section{Immediate context of the fulfilment statement}

Jesus' introduction into public life is by way of the ministry of John the Baptist, emerging from John's ministry (Nolland 2005:151). Matthew introduces the forerunner in the context most important to him - the proclamation of the kingdom of heaven (Luz 2007:133; Gundry 1982:43). Matthew anticipates the theme of righteousness with a message of repentance. Hagner (1993a:47) points out that the message of repentance is not tied directly to forgiveness as it is in Mark and Luke (Mk 1:4; Lk 3:3). Later Matthew will mention forgiveness in relation to the Eucharist and the blood of the covenant, and it is furthermore implicit in the confession of Matthew 3:6. Rather than forgiveness, Matthew's intent seems to be to place the idea of righteousness in contrast to those in need of repentance and the one who will satisfy all righteousness. Thus, setting the context of covenant (Mt 3:9) and kingdom (Mt 3:2), Matthew introduces his Christological figure at a baptism that is validated by the Holy Spirit and the declaration of sonship which is further verified in the temptation (Mt 4:1-11; Hagner 1993a:43).

Furthermore, the designation of sonship provides a glimpse of the baptismal experience in the early church (Johnson 2003:19). To determine how Matthew may have intended his readers to understand this, it is necessary to establish the setting for the fulfilment statement. Hagner (1993a:56) associates the fulfilment of righteousness in Matthew 3:15 with Matthew's phrase 'way of righteousness' (Mt 21:32) in salvation history. The former passage puts Jesus into salvation history, and the latter puts John into it as instrumental to Jesus' role in salvation history. Hagner's conception of fulfilment relating to the reaching of a new stage in salvation history reinforces this. Connors (2010:403) contends that the concepts of righteousness and fulfilment are complicated but, in reality, the simple understanding is to do the will of God.

\section{Influences on the genre of the text}

Greek culture is the first source for the consideration of Matthean structure. However, this is not found primarily in Platonic propositions or Aristotelian dialectics. Rather, the influence is found in Greek tragedy. The reason to begin here lies in the accepted fact that Matthew is a story. Kingsbury (1988:1-2) maintains that Matthew is a unified narrative or 'artistic whole'. The plot logically unites action, thought and characters.

This work contends that Matthew's evaluative point of view is in Matthew 1:1 - Jesus the Christ, son of David, son of Abraham. Whether this is viewed as the title to the book or the introduction to the first section of Matthew, it is obvious that this phrase lies at the heart of the kingdom message and Matthean purpose (cf. Kingsbury 1998:19-20). This simple phrase condenses the context, showing Jesus as the Christ (Christology), son of David (Kingdom), son of Abraham (Covenant).

\section{Setting the stage}

Matthew carefully creates a dramatic effect when Jesus arrives on the scene on cue ( $\tau$ ó $\varepsilon ;$ Mt $3: 13$ ). The prompt is the blistering statement of judgement that is incited by the presence of Matthew's leading antagonist, the Pharisees. ${ }^{1}$ John's bewildered reaction to Jesus' request shifts the attention to Jesus. Up to this point, Jesus has been passively involved. Notably, this fulfilment passage involves a physical action (Nolland 2005:151).

Matthew sets the stage for the baptism fulfilling righteousness by introducing the kingdom or reign ( $\beta \alpha \sigma 1 \lambda \varepsilon i$ í $\alpha$ ) by confirming the conflict between the Messiah and Israel that begun in chapter 2, and by previewing the messianic judgement of

1.This author has demonstrated in his doctoral dissertation (McCuistion 2013) that the form of Matthew's story is that of a Greek drama. Matthew's careful attention to detail has provided the necessary movements (Prologue, Parados, Episodes, Stasimons, Epode), intending his work for universal appeal and/or acceptance to support the advancement of the Gospel to all cultures and communities. 
the Son of Man. All of this is set in the forerunner's ministry of preaching and baptising, climaxing in the arrival of Jesus (Luz 2007:139-140). The movement of the drama is definite. Jesus has in mind to be baptised by John. Davies and Allison (1988:320) see the drama flow as Jesus arrives, is baptised, and then the heavenly voice speaks. They note that Matthew 3:14-15 are redactional and not part of the narrative. Their emphasis seems to concentrate on the last two verses of the pericope. Hagner (1993a:54) agrees with the emphasis on the descent of the Spirit as he notes that the crowd probably did not hear the voice. Luz (ibid:143) seems to reinforce this by minimising the baptism, making it of lesser importance than Mark. The reason for these views seems to be the emphasis on the heavenly vision. There are at least two acceptable reasons why this could be acceptable. Firstly, there is Matthew's use of 'behold' (iסoú). He uses the term 62 times in 59 verses throughout his work. This seems to be a catchword for him when he points to a definite action. Next, it is often connected with some type of celestial vision (Mt 1:20; 2:9, 13; $4: 11 ; 17: 3,5 ; 28: 2,9)$. Comparing the baptismal account and the transfiguration, Talbert (2010:58) and Davies and Allison (ibid:320) demonstrate the parallel supporting the climax of the vision in Table 1.

Davies and Allison (1988:320) point out that this parallel is not exact. In the transfiguration account, the heavenly proclamation does not terminate the story. Additionally, there is dialog (Mt 17:4) that has no parallel in the baptism account.

Whilst this approach places emphasis on the affirmation rather than the setting, it is not without difficulties. Firstly, it minimises the setting which is necessary for the proclamation to make sense. Additionally, it provides the reference for the declaration of sonship. Hence, it is appropriate to ask why God used these specific events to frame his proclamation. Each event is significant in itself, yet it is best seen as a whole. Furthermore, the scene would have been dynamic without the proclamation. Rather than the scene leading to the proclamation, the proclamation would seem to enhance the significance of the events (baptism and transfiguration respectively). It is not a question of the value of the heavenly affirmation. However, the setting was enhanced by the affirmation. Thus, the 'fulfilment' gives context to the affirmation - providing a special significance that it would not have had otherwise.

From here it is essential that the attention turn to the element of the fulfilment that produced the confirmation. Against Hagner (1993a:54), the baptism lay in the centre as can be seen by this chiastic outline:

\begin{tabular}{lll}
\multicolumn{3}{l}{ TABLE 1: Parallels between Jesus' baptism and transfiguration. } \\
\hline Baptism & Parallel & Transfiguration \\
\hline $3: 13-16 a$ & Setting & $17: 1-2$ \\
$3: 16 \mathrm{~b}$ & And behold & $17: 3 \mathrm{a}$ \\
$3: 16 \mathrm{c}$ & Vision & $17: 3 \mathrm{~b}$ \\
$3: 17 \mathrm{a}$ & And behold & $17: 5 \mathrm{~b}$ \\
$3: 17$ & Heavenly Voice & $17: 5 \mathrm{c}$ \\
\hline
\end{tabular}

Chiastic outline of the centrality of Jesus' baptism John's proclamation regarding Jesus Jesus comes to John Jesus is baptized to fulfil all righteousness

The Holy Spirit comes to Jesus

The Father's proclamation regarding Jesus

There is a distinctive movement in this from the human to the divine and a unity created between the two by the physical action and God's proclamation. Is it a picture of the incarnational theology of Matthew and the uniting of divinity and humanity? Additionally, if it is true that the baptism is at the centre of this pericope, another question is raised: How does the physical action of baptism fulfil righteousness? The examination of this should shed light on Matthew's possible intentions.

\section{Jesus' baptism fulfils all righteousness}

Davies and Allison (1988:323-324) list what they consider to be the seven most viable answers regarding how Jesus' baptism fulfils all righteousness:

1. It was the Messiah's task to bring the total will of God.

2. Jesus' baptism illustrated Jesus' death.

3. It was an example to Christians.

4. All divine ordinances, of which baptism is one, must be fulfilled.

5. Jesus validated John's ministry.

6. It was a right action intended to remove offense.

7. Jesus was fulfilling prophecy.

They agree that number 7 is the most convincing as it fits with the 13 fulfilment statements recorded by Matthew.

One apparent problem with all of these is that they cannot be supported contextually. With the exception of number 7 , these answers anticipate a developed theology that may have been present in the church teaching, but is not necessarily present in Matthew. Thus, the question is raised whether this can be answered contextually or we must depend on the larger, historical setting to determine the meaning. It will be beneficial to explore both.

In context, Matthew ties the baptismal scene to the preceding

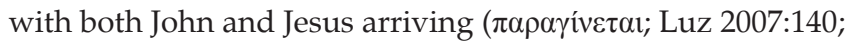
Robertson 1997). Jesus' arrival is Christological in nature as visualised by the use of $\tilde{\eta} \lambda \theta$ ov in Matthew 5:17 (Viljoen 2011:394-395). The Christological nature of this pericope is evident in that John's prophetic ministry for Matthew is that of Elijah's (Mt 11:14; 17:11-13), preparing for the day of the Lord (Davies \& Allison 1988:289).

Without introduction Matthew connects John's preaching with the practice of a baptism accompanied by confession of sins. Hagner (1993a:46) comments that there is no certain background for this practice except the more likely practice 
of the same in the Qumran community. He also suggests that whilst proselyte baptism is not a certain background, it is extraordinary that Jews were submitting to a rite that was normally associated with the initiation of Gentiles into Judaism. Nolland (2005:141) comments that Old Testament water rituals were for purification, but not tied directly to the removal of $\sin$. Rather, the purification was metaphorical (cf. Is 1:16-17; Jr 4:14). Additionally, Luz (2007:136) raises an important point by noting that, whilst Mark states John's baptism was for the remission of sins ( Matthew associates confession with John's primary message of repentance (Mt 3:2). From this, it would seem that Matthew is indicating a shift in perspective that could be the basis for the post-resurrection practice of baptism. However, the text gives no indication of this.

Matthew has the religious leaders (Pharisees and Sadducees)

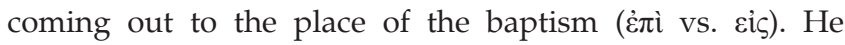
does not make it clear whether it was their purpose to be baptised, since غ̇ $\pi$ ì with the accusative can relate to location, not purpose (Köhler 1990:22). According to Luke (Lk 3:7-9), John does not single out the religious leaders. However, Matthew certainly makes it evident that they are the catalyst for the scathing remarks. Furthermore, the introduction of the antagonist accelerates Matthew's emphasis on a baptism greater than his own - effected by one greater than himself. John's preparatory ministry introduces the greater one whose baptism has a greater effect. This is obvious from the rebuke John gives the religious leaders. He implies that the act of baptism may be hypocritical, unless one can produce actions fitting the confession of their sins. His reprimand gives opportunity to contrast them, as religious leaders, against one who has the right to baptise in a greater way. Additionally, Matthew uses this episode with John and the Pharisees to put this into covenant context by the use of the

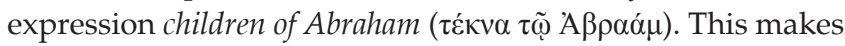
a strong connection back to Matthew 1:1 and Jesus as the son of Abraham.

It is important to the context to consider why Matthew chooses to include this group. Powell (2009:9) suggests that the use of a social-scientific approach to the interpretation gives a historical perspective that discovers more about the world (meaning society) that produced the gospel. This approach is rooted in the idea that the author and reader of another era are foreign to the modern Western world. Nonetheless, with the help of the social-scientific approach, the goal is to recover the ancient social system (Malina 2009:157). The crowds and the religious group would represent common Judaism, prerabbinic legalism and the religious political elements of the society. This social mix provides a cross section of Matthew's Judaism - the primary audience for both John and Jesus. Just as the prophets of old (pre-exilic), John takes his audience to a place of judgment (pictured as a harvest).

All three of the Synoptic Gospels allow for a public setting as the baptism is introduced by John's practice of baptising. Tó $\varepsilon \varepsilon$ (Mt 3:13) controls Matthew's proximity of Jesus' baptism to the others. Luke chooses not to use an adverb that can mean a distant or immediate time (Balz \& Schneider 1990c). Rather, he uses the punctiliar aorist ( $\beta \alpha \pi \tau \iota \sigma \theta \tilde{\eta} v \alpha \iota, L k 3: 21)$, indicating the proximity of the two accounts. However, some would move the scene to a private setting (Witherington 2006:80; France 1985:99). Against this, Luz (2007:140) suggests that the baptism is actually the climax to the setting. As such, this would seem to include the audiences, anticipating several questions that could arise. One such question would be whether the conversation between John and Jesus was public. If so, would the audience anticipate then that this is the one of whom John just spoke? Additionally, would they question Jesus' need for a baptism of repentance and confession? Hagner (1993a:54-55) contends that John's contesting of Jesus' need for baptism would eliminate this. As this section stands, little depends on the participation of the audience. Rather, as Matthew tells the story, the significance lies with John and Jesus. Matthew is clear with this in that the fulfilment of righteousness requires both of them. Jesus involved John by making it 'fitting for us'. This draws his forerunner, whose message of the kingdom has prepared for this event, into his actions. This is significant in that it provides an absolute tie between Jesus' ministry of fulfilment and the act of baptism. Later (Mt 21:32), Jesus will tell the Pharisees that John came in the way of righteousness. Thus, Blomberg (2009:258) insists that Jesus' statement of righteousness is a validation of John's baptism, whereas Davies and Allison (1988:170-171) limit this to John living a moral life. However, the product of righteousness is not the whole of what righteousness is. The ontological aspect of God as righteous is at the root of all actions (God or humanity). In this same way, John coming in righteous and Jesus fulfilling it satisfies a greater reality than moral living. This would seem evident in that John's demand for fruit in keeping with repentance would be a result of his baptism - not the way to accomplish it. Olender (2008) contends that whilst scholars debate righteousness as either a gift or a demand, neither is naturally inherent in the concept. Righteousness is certainly active, but does not necessitate a salvation by works. Hagner (1993a:56-57) concurs by stating that salvation by works is a faulty perception of Matthew's commitment to the importance of righteousness that is fully realised in the Gospel of the Kingdom.

The descent of the Spirit and the affirmation of God have a significant role, as is evident in the fact that this is a common tradition in the Synoptic Gospels. For Matthew, the purpose may be to validate the 'son of' concept of his thesis (son of David and Abraham in Mt 1:1). If so, this elevates the messianic concept from a pure physical lineage to that of the divine. Additionally, with the enhancement of 'the beloved' (o $\alpha \gamma \alpha \pi \eta \tau$ ó; lit. the son of me, the beloved) the concept is enlarged to involve not only Jesus, but also all the covenant people. Keener (1999:135) connects the phrase the beloved to God's special love for Israel as his son. Furthermore, Keener emphasises that Matthew's use of 'the beloved' indicates God's special focus on Jesus, also a son. This special relationship is first realised with Abraham, the father of the covenant, when he is called the friend of God (2 Chr 20:7; Is 41:8; Ja 2:23). The Hebrew word עגזר is stronger than the Greek 


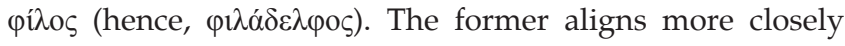
with $\alpha \gamma \alpha \pi \alpha \omega \omega$ (Gesenius \& Tregelles 2003:16). However, the implication in both terms is that of a deep love, as God would have for a son. In the 'beloved son' statement, Mounce (1991:26) finds a correlation to when God told Abraham to take the son he loves and offer him as a burnt offering (Gn 22:2).

The final contextual element is the great pleasure God receives in his beloved son. Légasse (1990:75) notes that God

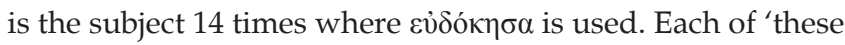
have a Christological, soteriological, or prophetic-apostolic accent'. This is more obvious in Matthew 17:5 where the

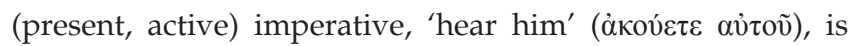
added (compare Ps 149:4 where God takes pleasure in his people).

Contextually, there are hints as to the meaning of the fulfilment of righteousness. However, the study must broaden the historical-critical investigation to encompass a much larger scope in order to have a better understanding. The historical-critical method uses many disciplines in conjunction with each other. With these, the historical-critical method attempts to arrive at the meaning of the text in the original context. This places the interpreter in the world of the text (Hagner \& Young 2009:11-15).

The easy tendency would be to Paulinise this and look to his theology for an explanation. Whilst this may offer some benefit, this alone is not sufficient. However, Paul does provide a good starting point for the conversation. He told

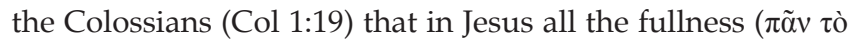
$\pi \lambda \eta \dot{\rho} \omega \mu \alpha)$ dwelt. Since Paul was a contemporary of Matthew, it may well be assumed that the early tradition contended that all the fullness in Jesus is all-encompassing, including this concept of righteousness. An understanding of the later, historical landscape will prove helpful.

\section{Tradition and the Church Fathers}

In the previous section, the literary and historical setting satisfied the historicity of the incident. From that study, several of the criteria that Evans (2009:138-143) listed provides a framework for assessing biblical literature. Firstly, historical coherence is obvious in that recorded church history accepts the historicity of the baptism (cf. Irenaeus' Against Heresies 3.12; Clement's Stromata 1.21). In addition to this historical claim, there are multiple attestations in that all of the Synoptic Gospels recorded the event. This encourages the readers to accept the tradition as fact. Additionally, dissimilarity is evident in the use of a Gentile practice (baptism for proselytising) associated with Jesus' introduction into the Jewish religious culture. These lend to the authenticity in that Matthew's Gospel moves toward a universal orientation (cf. Mt 28:18-20). Thus, historicalcritical studies, whilst not easy, are rewarding and provide an important perspective of Jesus.
This perspective is valuable, but not conclusive in answering the questions regarding the meaning of the fulfilment of righteousness. This is foundational, but the wider vision is necessary to discover what Matthew may have intended. Thus, whilst understanding that Matthew is presenting a historical drama, it is beneficial to understand that the Sitz im Leben [situation in life] of Matthew's community is post-resurrection and that this perspective may be present in the work. The post-resurrection religious experience of his community could well support a myopic perception of Jesus' Christological status in the larger faith community. This perception could then influence the interpretation of the reality of the experience. In dealing with a post-resurrection religious experience, Johnson (2010:95) admits that there are problems capturing personal experiences, as they are a blend of the objective and subjective. He states that it is difficult to make a distinction between objectivity and subjectivity. Many events tend to be viewed as personal experiences, which Johnson (ibid:96) considers an encounter with God realised in unexpected ways, making it impossible to deny his presence. Writing some years after the historical events of Jesus' death and resurrection, Matthew's church understands that Jesus' baptismal encounter was a historical event. However, there may be evidence that they also read more into the experience that Matthew shared. This practice of the church makes the historical event a personal experience. To illustrate, Mueller (2007:143) draws an image of a pebble thrown into a pond. The pebble is the historical event that Mueller calls the 'Jesus event'. The ripples created by that affect everything they encounter. Some of the things moved by the ripples develop ripples of their own. Such is the impact of the resurrection faith of Matthew's and every Christian community. This seems to be the case with this account as seen in the developing traditions and their effect on the resulting theology. Thus, it may be assumed that Matthew's community would be aware of the Christological impact of the baptism of righteousness in light of the tradition that developed.

Twice Paul states that he delivered what he received (1 Cor 11:23; 15:3). Additionally, he instructed Timothy to teach what was taught to him and then those he taught were to teach others ( $2 \mathrm{Tm} 2: 2)$. At the time when there was no canon, the tradition was vital (cf. 1 Cor 11:2; 2 Th 2:15; 3:6). However, in the canon only Luke in Acts mentions John's baptism. In Acts 1:22, it is a historical marker designating the terminus a quo [origin] for apostolic companionship with Jesus. The remaining accounts (Ac 10:37; 13:24; 18:25; 19:34) acknowledge the nature of John's baptism. Contrasting to Acts 10:36-37 and the message of peace, John's baptism is a terminus a quo relating to the shift in the message. The next occurrence (Ac 13:24) is similar to the one in Acts 10:36. The final three are from an account where Apollos, the Alexandrian, was preaching but knew only John's baptism. $\mathrm{He}$ was immediately instructed that Christian baptism exceeded John's. The result was a baptism in (into) the name

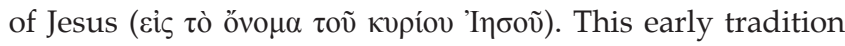
demonstrates a significant shift in the nature of baptism. The original ontological mark was that of John's mission as the forerunner. The shift was to that of Jesus. The reason is not evident until later writings. 
Ignatius is the earliest of the Christian writers to give insight into the tradition that had developed. In his Epistle to the Ephesians (18.2), he states that Jesus' birth and baptism was

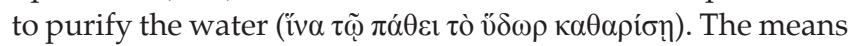
of purification was his $\pi \dot{\alpha} \theta$ oc. The Apostolic fathers provide no clear sense of the word, but it may carry the same as the New Testament use (Schneider 1964:904-924). Lake (19121913:193, note I) comments that $\pi \alpha \dot{\theta} \theta$ o alludes to the Baptism, not to the Passion. It would seem that either would be fitting, since the water would reference the baptism as empowered by the sacrificial death of Jesus. Additionally, this would align with Paul's understanding in Romans 6 where the baptism is the means of contact to the death and the benefits of that death.

Another interesting text comes from the Pseudo-Clementine Literature (Recognitions of Clement, 1.48), where the writer allegorises water of Jesus' baptism as a suppressant for the sacrificial fires of the Old Testament economy. This implies a pivotal event that connects his actions with the end of the economy and the introduction of his own. Tertullian (1885a:160) picks up this same theme with reference to the terminus ad quem [aim] of the law and the prophets with John (Mt 11:13), making John the beginning of the fulfilment period. In this, he states that Christ's baptism sanctified the waters. He continues this thought in On Modesty (Tertullian 1885b:100) with a reference to the water and blood flowing from Jesus' side at the crucifixion. He calls these elements the materials (Lat. paratura, equipment) of baptism (cf. Jn 5:6-12). As in Romans 6, there is a direct connection between the baptismal waters and the passion of Christ.

From this, it may be possible to see why Paul's shift was to the ontological marking achieved in the baptism. Thus, rather than Paulinising John's baptism, it is tenable that Paul knew and accepted the tradition that Jesus' baptism effected an ontological change in the act that effectually united the essence of the Christ to the baptismal waters. In this, the baptism of righteousness shared the same substance

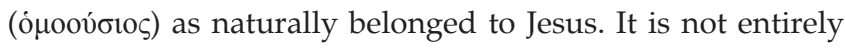
clear why baptism plays no role in the Synoptic account of Jesus' ministry (contrast Jn 3:22; 4:1-2), but the best suggestion seems to be (though this is not worked out in any systematic way) that there is a general assumption that those who respond to Jesus' ministry have already been baptised by John. Nolland (2005:141-142) comments that the baptism in Matthew 28:18 emerges because of the Gentile. Further,

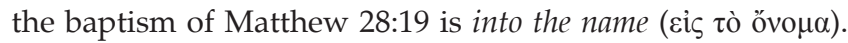

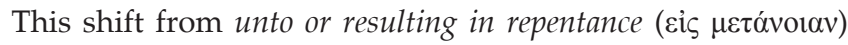
signifies the allegiance to or association with the power and authority of Jesus. All of this is an indication that the baptism of Matthew 3:15 that satisfies righteousness is more significant than Pryzybylski's (1980:1) categories for the term.

\section{Cultural context and link to Matthew 5:17}

The covenant context of this fulfilment statement is set in John's reference that having lineage to Abraham (Mt 3:9) is not enough since God had created the heritage, of which they were so proud, from Abraham who was a lifeless rock (Davies \& Allison 1988:308), being too old to bear children. Gundry (1982:46) puts it well when he states that they were willing to exchange genuine righteousness for their foolish pride. In reality, the Christological significance of the son who pleases God as Abraham did, should be their emphasis and priority. The religious leaders (and people according to Luke's account) needed to replace their cultic pride with pride in the work of God. The expression 'fulfil' anticipates that there was some event, action or concept that was not completely satisfied. That is, the event, action or concept required something more to fully satisfy its potential. Matthew found satisfaction in the fullness of righteousness. Ultimately, the reign of Jesus is realised in his authority to administer justice (based on perfect righteousness):

His winnowing fork is in His hand, and He will thoroughly clear His threshing floor; and He will gather His wheat into the barn, but He will burn up the chaff with unquenchable fire. (Mt 3:12)

The context firmly anchors the fulfilment statement into Matthew's milieu. However, there is a sense in which Matthew leaves the reader wanting. Covenant, Messiah and Kingdom anticipate, at least for the historical economy, the necessity for the clear word of God. God had not hesitated to make his will known previously. If Matthew is attempting to restore the Abrahamitic tie, then, of necessity, the question of the law in relationship to righteousness is anticipated. Thus, the expectation is that the fulfilment of righteousness mandates a statement regarding the law. If righteousness is now fulfilled, what is the status of the law? Is it ineffectual? Viljoen (2011:387) argues that Matthew presents Jesus as defending 'the continuing validity of the Torah (Matt. 5:1720) in a cohesive manner'. This is anchored to the established standard that fulfilled righteousness. Both the standard and the fulfiller are tested in the wilderness where the affirmation of sonship is challenged with the trifold temptation of 'if you are the son'. Thus, Matthew's drama has moved from the incarnational scene that fleshed out righteousness to Jesus' formal proclamation of his authority as the one who pleases God (Mt 3:17; cf. Mt 17:5). Although Matthew fills in the drama of the wilderness and the beginning of ministry, it is apparent that the fulfilment of righteousness concept is not complete. It is as if Matthew 3:15 anticipates something else. It anticipates Matthew 5:17 (Luz 2007:140). Thus, an examination of Matthew 5:17, and ultimately the surpassing righteousness of Matthew 5:20, is needed.

\section{Implications}

Amongst the many possible implications of this article, one of importance relates to the physicality of the baptism. As noted above in the discussion regarding the setting, the action of the baptism demonstrated a definite movement from the human to the divine. Paul emphasises the necessity of this movement in Colossians 1:12-13 where he states that there is $\mu \varepsilon \theta i \sigma \tau \eta \mu$ taking place which Balz and Schneider (1990a:401) define as a removal or transplant. There is a distinct dichotomy between the domain of darkness ( $\dot{\varepsilon} \xi o u \sigma i \alpha$ 
тои̃ бко́тоuৎ) and the Kingdom of the beloved Son ( $\beta \alpha \sigma i \lambda \varepsilon i ́ \alpha v$

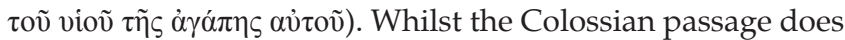
not involve baptism, Romans 6, which defines the dichotomy as between the ö $\pi \lambda$ ov [tool; weapon] of righteousness and unrighteousness, focuses the transition on the baptism. The $\mu \grave{\gamma} \gamma \varepsilon$ voı the contrast between continuing in sin and living rightly. Paul then firmly contends that it is baptism that effects this because of its connection with the death, burial and resurrection of the Christ. Ignatius will reinforce this with the tradition that Jesus' birth and baptism was to purify the

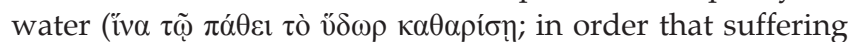
purifies the water). This, along with the other examples given above, demonstrates that Christian baptism is validated by Jesus' baptism and the passion. As the suffering ( $\pi \dot{\alpha} \theta 0 \varsigma$ ) was physical, so is the baptism. The absurdity of accepting the suffering of Christ as physical, but moving the baptism to spiritual, borders on a gnostic-type theology that purposefully separates reality from the metaphysical.

Another implication is in the application of the ontology of Jesus as God to the act of baptism. This is tied to the first implication in that the effects of baptism are directly related to the effects of the $\pi \dot{\alpha} \theta$ os. Paul makes this very clear in

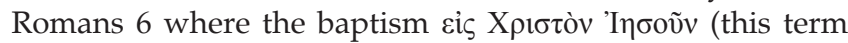

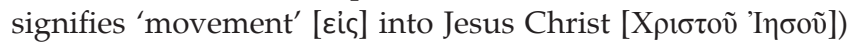

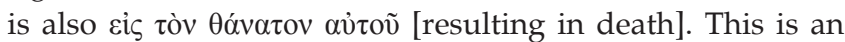
ontological relationship where what is effected by being in Christ ( $\dot{\varepsilon} v$ X Christ experienced. Both of these have the end product of life (Rm 6:22-23). This understanding of an ontological mark imprinted at baptism is not without difficulty. It could easily be assumed that, once marked, the very nature of Christ would not be infused into the person, thus overriding the very nature of Adam in humanity. This is a valid assumption - one that Matthew handles. Matthew demands a resultant lifestyle that equates to the repentance that is the product of the baptism. The principle here is that the baptism must have an equal or balanced effect to it. This is the resultant lifestyle. Paul picks up this very theme in Romans 6 by demanding that the baptism into the death of Christ be the very motivation for presenting one's self to God as alive from

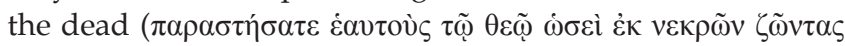

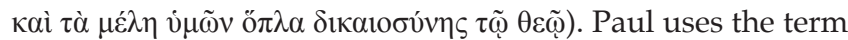
$\pi \alpha \rho \alpha \sigma \tau \eta \dot{\sigma \alpha \tau \varepsilon}$ [present or appear] five times in Romans 6 to reinforce the idea that the Christian has a responsibility (the form is aorist active imperative, and thus a command) based on the baptism. It is noteworthy that Paul uses the aorist when referencing the idea of presenting $(\pi \alpha \rho \alpha$ [beside] + i $\sigma \tau \eta \mu$ [stand or place]) righteousness. This past experience is tied irrevocably to the baptism. This is motivated by our love for Christ (2 Cor 5:14, where love monopolises us). For Paul thus the baptism becomes the motivation and the presentation of righteousness - not the uncontrollable source. This is further understood by Peter's statement that the Spirit is a gift given at baptism (Ac 2:38). At the least, the Spirit will work in the individual to convict of sin, righteousness and judgement to come (Jn 16:7-11). To support this, Paul assures the Romans that there is a responsibility. It is to 'walk' ( $\pi \varepsilon \rho 1 \pi \alpha \tau \varepsilon$ ' $)$; about, walk, conduct oneself, live; Balz \& Schneider 1990b:75).

\section{Conclusion}

Matthew's determination to emphasise the righteousness of God is best introduced in the fulfilment statement of Matthew 3:15. Here, Matthew places Jesus in the unique position as the one qualified to fully satisfy righteousness. Setting the stage within a Jewish context, Matthew quickly emphasises that the son of David and Abraham has the full privilege of presenting the ontological nature of God that is understood to be right. This rightness is expressed physically in the incarnation, and continues to be available to Matthew's community (and $\tau \grave{\alpha}$ č $\theta v \eta$, the ethnic, meaning the world) by means of the water of baptism. Not that the water is righteous, but that Jesus has made sacred that which was common for the distinct purpose of introducing humanity to his nature which is righteous. The baptism becomes the incarnational agency through which the righteousness of God revealed in the gospel (Rm1:16-17) is accessed by the believing world. 'Go', Matthew insists (Mt 28:18). As you go, make disciples. These disciples must then be baptised into the name (cis tò óvo $\mu \alpha)$, for in the name, the very nature of the person resides.

\section{Acknowledgements Competing interests}

The authors declare that they have no financial or personal relationship(s) that may have inappropriately influenced them in writing this article.

\section{Authors' contributions}

C.W. (Saint Leo University and North-West University) and F.P.V. (North-West University) supervised P.R.C. (Saint Leo University and North-West University) in his research and writing of the article.

\section{References}

Balz, H.R. \& Schneider, G., 1990a, ' $\mu \varepsilon \theta i \sigma \tau \eta \mu$ ', in H.R. Balz \& G. Schneider (eds.), Exegetical Dictionary of the New Testament, pp. 401, Eerdmans, Grand Rapids, MI.

Bergmeier, R., 1990b, ' $\pi \varepsilon \rho ı \pi \alpha \tau \dot{\varepsilon} \omega$ ', in H.R. Balz \& G. Schneider (eds.), Exegetical Dictionary of the New Testament, pp. 76-76, Eerdmans, Grand Rapids, MI.

Balz, H.R. \& Schneider, G., 1990c, 'Tótz', in H.R. Balz \& G. Schneider (eds.), Exegetical Dictionary of the New Testament, pp. 367, Eerdmans, Grand Rapids, MI.

Blomberg, C., 2009, Jesus and the Gospels: An introduction and survey, $2 \mathrm{nd}$ edn., B\&H Academic, Nashville, TN.

Connors, A.F., 2010, 'Matthew 3:13-17', Interpretation: A Journal of Bible \& Theology 64 (4/Oct), 402-404.

Cook, R.M.J., 2008, Modern Jews engage the New Testament, Jewish Lights, Woodstock, VT.

Davies, W.D. \& Allison, J.D.C., 1988, The Gospel according to Saint Matthew: I-VII, T \& T Clark, Edinburgh.

Eliott, M.A., 1992, 'Israel', in J.B. Green \& S. McKnight (eds.) Dictionary of Jesus and the Gospels, pp. 356-363, InterVarsity Press, Downers Grove, IL.

Evans, C.A., 2009, 'Historical Jesus studies and the Gospel of Matthew', in M.A. Powell (ed.) Methods for Matthew, pp. 118-153, Cambridge University Press, Cambridge. France, R.T., 1985, Matthew, InterVarsity Press, Nottingham.

Gesenius, W. \& Tregelles, S.P., 2003, Gesenius' Hebrew and Chaldee Lexicon to the Old Testament Scriptures, Logos Research Systems, Bellingham, WA.

Gundry, R.H., 1982, Matthew: A commentary on his literary and theological art, Eerdmans, Grand Rapids, MI.

Guthrie, D., 1990, New Testament Introduction, InterVarsity Press, Downers Grove.

Hagner, D.A., 1993, Matthew 1-13, vol. 33a, Thomas Nelson, Nashville, TN. (World Biblical Commentary Series).

Hagner, D.A. \& Young, S.E., 2009, 'The Historical-Critical Method and the Gospel of Matthew', in M.A. Powell (ed.), pp. 11-43, Methods for Matthew, University Press, Cambridge.

Johnson, L.T., 2003, The Creed: What Christians believe and why it matters, Doubleday, New York. 
Johnson, L.T., 2010, The writings of the New Testament: An interpretation, 3rd edn., Fortress Press, Minneapolis, MN.

Keener, C.S., 1999, A commentary on the Gospel of Matthew, Eerdmans, Grand Rapids, MI.

Kingsbury, J.D., 1988, Matthew as story, 2nd edn., Fortress Press, Philadelphia, PA.

Kingsbury, J.D., 1998, Matthew, Evangel Publishing House, Nappance, IN.

Köhler, W., 1990, 'ह̇лi', H.R. in Balz \& G. Schneider (eds.), Exegetical Dictionary of the New Testament, pp. 21-23, Eerdmans, Grand Rapids, MI.

Lake, K. (ed.), 1912-1913, Lake's apostolic fathers in English, Macmillan, London.

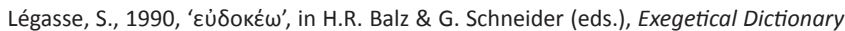
of the New Testament, p. 75, Eerdmans, Grand Rapids, MI.

Luz, U., 2007, Matthew 1-7, Fortress Press, Minneapolis, MN.

Malina, B.J., 2009, 'Social-Scientific Approaches and the Gospel of Matthew', in M.A. Powell (ed.), Methods for Matthew, pp. 154-193, Cambridge University Press, Cambridge. http://dx.doi.org/10.1017/CBO9780511627118.008

McCuistion, P., 2013, 'Covenant, Christology and Kingdom in Matthew's use of Plēróō', PhD thesis, Unit for Reformed Theology, North-West University.

Mounce, R.H., 1991, Matthew, Hendrickson, Peabody, MA.

Mueller, J.J., 2007, Theological foundations, Anselm Press, Winona.

Nolland, J., 2005, The Gospel of Matthew: A commentary on the Greek text, Eerdmans, Grand Rapids, MI.
Olender, R.G., 2008, 'Righteousness in Matthew with implications for the declaration of Joseph's righteousness and the Matthean exception clauses', PhD thesis, Theological Studies, Southeastern Baptist Theological Seminary.

Powell, M.A., 2009, Methods for Matthew, Cambridge University Press, New York, NY. http://dx.doi.org/10.1017/CBO9780511627118

Robertson, A.T., 1997, Word pictures in the New Testament, Logos Research Systems, Oak Harbor, WA

Pryzybylski, B., 1980, Righteousness in Matthew and his world of thought, Cambridge University Press, Cambridge.

Schneider, J., 1964, ' $\pi \alpha ́ \sigma \chi \omega$ ', in G. Kittel, G.W. Bromiley \& G. Friedrich (eds.), Theological Dictionary of the New Testament, pp. 904-924, Eerdmans, Grand Rapids, MI.

Talbert, C.H., 2010, Matthew, Baker Academic, Grand Rapids, MI.

Tertullian, 1885a, 'An answer to the Jews', in A. Roberts, J. Donaldson \& A.C. Coxe (eds.), The Ante-Nicene Fathers. Latin Christianity: Its Founder, Tertullian, p. 160 Christian Literature Company, Buffalo, NY.

Tertullian, 1885b, 'On modesty', in A. Roberts, J. Donaldson \& A.C. Coxe (eds.), The Ante-Nicene Fathers. Fathers of the third century: Tertullian, Part Fourth. (Minucius Felix. Commodian. Origen, Parts First and Second), p. 100, Christian Literature Company, Buffalo, NY.

Viljoen, F.P., 2011. 'The foundational statement in Matthew 5:17-20 on the continuing validity of the law in Matteus 5:17-20', In die Skriflig 45(2\&3), 385-407.

Witherington, B. III, 2006, Matthew, Smyth \& Helwys, Macon, GA. 